\title{
Trophoblast of domestic and companion animals: basic and applied clinical perspectives
}

\author{
Augustine Thomas Peter ${ }^{1,4}$, Mohd Amin Beg ${ }^{2}$, Ejaz Ahmad $^{2}$, Don Rick Bergfelt ${ }^{3}$ \\ ${ }^{1}$ Department of Veterinary Clinical Sciences, College of Veterinary Medicine, Purdue University, West Lafayette, IN, USA. \\ ${ }^{2}$ King Fahd Medical Research Center, King Abdulaziz University, Jeddah, Kingdom of Saudi Arabia. \\ ${ }^{3}$ Department of Biomedical Sciences, Ross University School of Veterinary Medicine, Basseterre, St. Kitts, West Indies.
}

\begin{abstract}
The trophoblast is the single most important functional structure of the placenta that mediates the attachment of the blastocyst to the endometrium. Trophoblast has the capability to proliferate in concert with the uterine epithelium to form the only site for nutrient and metabolic exchange between the fetus and dam throughout pregnancy. Trophoblast is made up of a remarkable versatile epithelium showing great capacity for invasion, cell fusion, hormone production, specific nutrient absorption, selective transport, active metabolism, and has the ability to resist maternal immunological attack. These functions are attributed to its inherent ability to synthesize many developmental factors or molecular regulators. While there is an abundance of publications available on the structural, functional, and clinical relevance of the placenta in various mammalian species, a comprehensive review on the comparative aspects of the trophoblast of domestic and companion animals is lacking. Besides, a timely description on the clinical perspective on the functional aspects of the trophoblast in relation to pregnancy diagnosis, placental insufficiency, pregnancy loss, and structural abnormalities of domestic and companion animals is necessary. A brief description on the basic chronology of events in each animal is followed by the applied clinical perspectives of trophoblast. Both the above aspects of trophoblasts of domestic and companion animals including the terminologies are summarized in tables to facilitate discussion.
\end{abstract}

Keywords: clinical perspectives, domestic and companion animals, trophoblast.

\section{Introduction}

Viviparity and development of a placenta are major reasons for the success of vertebrates in colonizing all habitats, both terrestrial and aquatic. In eutheria, namely in placental mammals, the process of placentation is a pivotal event in the survival of the early embryo and maintenance of the developing fetus, yet it is one of the least understood aspects of reproduction and is often overlooked (Cross et al., 1994). In general, the placental-uterine interaction has two main functions: 1) provide oxygen, nutrient, and waste exchange and 2) minimize fetal rejection by the maternal immune system. The importance of these functions has resulted in development of a placenta that is structurally diverse among mammals (Wooding and Burton, 2008). However, regardless of the structural variations, each placenta has a trophoblast. The trophoblast is the single most important functional tissue of the placenta that mediates the attachment of the blastocyst to the endometrium and serves as an immunological barrier through synthesis of many developmental factors or molecular regulators to facilitate implantation and prevent maternal rejection. Any perturbation and interference in the structural and functional aspects of the trophoblast can result in loss of pregnancy.

While there is an abundance of publications available on the structural, functional, and clinical relevance of the placenta in various mammalian species (Carter and Enders, 2004, 2013; Enders and Carter, 2006; Miglino et al., 2006; Wooding and Burton, 2008; Carter and Mess, 2017), this review is primarily intended to provide a comprehensive and comparative up-date on the trophoblast of domestic and companion animals. Secondarily, this review will provide a clinical perspective on the functional aspects of the trophoblast in relation to pregnancy diagnosis, placental insufficiency, pregnancy loss, and structural abnormalities.

\section{Trophoblast}

The term 'trophoblast' was introduced in 1888 by the Dutch embryologist Hubrecht during his study of early postimplantation development of the embryo in the hedgehog (Hubrecht, 1889). The term trophoblast is derived from two Greek words, namely, trephein: to feed and blastos: germinator. During the initial stages of embryo development, two successive differentiation events lead to segregation and formation of cell lineages. The first event begins during compaction where the outer layer of cells segregates to form a layer of cells that will eventually become the trophoblast, whereas the inner layer of cells (inner cell mass, ICM) produces the embryonic lineages. The second round of segregation divides the ICM into primitive ectoderm and endoderm. The trophoblast makes its first appearance in the life of the embryo in blastulation (formation of a cavity within the embryo). In general, the process of blastulation leading to the development of a blastocyst, an early embryo, is accompanied by the formation of a central cavity with a single outer layer of ectodermal cells called 'the trophoblast'. The cells of the trophoblast are the first cells to differentiate in an embryo with a sole-function to sustain and protect the embryo. The term 'trophectoderm' is also used to describe these polarized cells since they are fated to differentiate into trophectoderm after gastrulation as it is then contiguous with the ectoderm of the embryo 
and become part of chorioallantois (Igwebuike, 2006). The trophoblast is a remarkable versatile epithelium showing great capacity for invasion, cell fusion, hormone production, specific nutrient absorption, selective transport, active metabolism, and has ability to resist maternal immunological attack. For this review, the authors prefer to use the term placenta referring to a structure that has both maternal (endometrium) and fetal (chorioallantois and amnion or simply the fetal membranes) components (Peter, 2013) and the term trophoblast to indicate the layer of cells (Leiser and Kaufmann, 1994; Hall et al., 2013) of the placenta that covers the external surface of the chorioallantois (Roberts, 1971; Igwebuike, 2006). Terminology used in early embryo and trophoblastic development is summarized in Table 1 and chronology of events of trophoblast development and function during pregnancy is summarized in Table 2 .

Table 1. Terminology of early embryo and trophoblastic development in domestic animals.

\begin{tabular}{|c|c|}
\hline Allantois & $\begin{array}{l}\text { A vascular, extraembryonic membrane that develops as a sac or diverticulum from } \\
\text { the ventral wall of the hindgut of the early embryo. }\end{array}$ \\
\hline Blastocoel & Fluid-filled cavity within the blastocyst. \\
\hline Blastocyst & $\begin{array}{l}\text { Transformed morula with blastocoel and inner cell mass which subsequently forms } \\
\text { embryo. }\end{array}$ \\
\hline Blastulation & $\begin{array}{l}\text { Refers to the process of differentiation of morula by the formation of a fluid-filled } \\
\text { cavity and inner cell mass. }\end{array}$ \\
\hline Chorion & $\begin{array}{l}\text { A layer formed by the trophoblast and extraembryonic mesoderm, and involved in } \\
\text { the formation of fetal components of placenta. }\end{array}$ \\
\hline Chorioallantois & Chorion combined with allantois. \\
\hline Chorionic girdle & Invasive component of equine trophoblast that forms the endometrial cups. \\
\hline Cytotrophoblast & Uninucleated trophoblast primarily capable of proliferation. \\
\hline Gastrulation & Differentiation of three germ layers ectoderm, mesoderm, and endoderm. \\
\hline Hatching & Release of blastocyst from zona pellucida. \\
\hline Hemophagous zone & $\begin{array}{l}\text { Marginal hematomas seen as circumferential bands in zonary placentas of carnivores } \\
\text { primarily associated with cytotrophoblast capable of phagocytosing maternal } \\
\text { erythrocytes. }\end{array}$ \\
\hline Implantation & Process of attachment of blastocyst to endometrium. \\
\hline Morula & $\begin{array}{l}\text { Zygote undergoes cleavage and becomes a multicellular sphere-like structure called } \\
\text { morula. Cells of the morula are known as blastomeres. }\end{array}$ \\
\hline Placenta & A structure comprised of maternal (endometrium) and fetal (chorion) components. \\
\hline Placentome & $\begin{array}{l}\text { A well vascularized structure found in pecoran ruminants resulting from the } \\
\text { interdigitation of the trophoblastic (cotyledon) and endometrial (caruncle) villi. }\end{array}$ \\
\hline Placentomal trophoblast & Trophoblast in the placentome. \\
\hline Syncytiotrophoblast & $\begin{array}{l}\text { Multinucleated trophoblast cells derived from cytotrophoblast primarily capable of } \\
\text { invasion. }\end{array}$ \\
\hline Trophectoderm & Outer layer of cells of blastocyst. \\
\hline Trophoblast & $\begin{array}{l}\text { In the chorioallantoic placenta throughout gestation the outermost fetal layer is } \\
\text { invariability the trophoblast }\end{array}$ \\
\hline Zygot & A fertilized oocyte. \\
\hline
\end{tabular}


Table 2. Chronological events during trophoblast development and function in domestic and companion animals.

\begin{tabular}{|c|c|c|c|c|c|c|c|}
\hline Species & $\begin{array}{l}\text { Stage of embryo at entry } \\
\text { into uterus } \\
\text { (days of entry from } \\
\text { ovulation) }\end{array}$ & $\begin{array}{l}\text { Trophoblast } \\
\text { differentiation } \\
\text { (day) }\end{array}$ & $\begin{array}{l}\text { Implantation } \\
\text { (day) }\end{array}$ & $\begin{array}{l}\text { Morphology of } \\
\text { placentation and its } \\
\text { impact on } \\
\text { trophoblast } \\
\text { attachment }\end{array}$ & Maternal-fetal relationship & $\begin{array}{l}\text { Trophoblastic factors in } \\
\text { maternal recognition of } \\
\text { pregnancy } \\
\text { (critical days) }\end{array}$ & $\begin{array}{l}\text { Gestation } \\
\text { length } \\
\text { (days) }\end{array}$ \\
\hline Cattle & Morula (4-5) & 6 & $22-25$ & Cotyledonary & synepitheliochorial & $\mathrm{INF} \tau(14-17)$ & 280 \\
\hline $\begin{array}{l}\text { Sheep \& } \\
\text { goat }\end{array}$ & Morula (4-5) & 6 & 15 & Cotyledonary & synepitheliochorial & $\begin{array}{l}\text { Sheep INF } \tau(10-12) \\
\text { Goat INF } \tau(16-17)\end{array}$ & 150 \\
\hline Pig & Morula (2) & 5 & 13 & Diffuse & Epitheliochorial & Estrogen (11-12) & 114 \\
\hline Horse & $\begin{array}{l}\text { Morula/early blastocyst } \\
(6-7)\end{array}$ & 6 & 40 & Microcotyledonary & Epitheliochorial & $\begin{array}{l}\text { Proteins/estrogen/ still not } \\
\text { clear (12-14) }\end{array}$ & 330 \\
\hline Camel & Hatching blastocyst (6.5) & 6.5 & 14 & Diffuse & Epitheliochorial & Not known & 390 \\
\hline Dog & $\begin{array}{l}\text { Morula/early blastocyst } \\
(11-13)\end{array}$ & $10-11$ & 17 & Zonary & Endotheliochorial & Absent/unknown & 60 \\
\hline Cat & Blastocyst (4-6) & 4 & 14 & Zonary & Endotheliochorial & Absent/unknown & 60 \\
\hline
\end{tabular}




\section{Cattle}

The embryo enters the uterus on day 5 post ovulation (ovulation $=$ day 0 ) and trophoblast is formed on day 6 of pregnancy, a time when blastulation occurs. The process of hatching (release of embryo from zona pellucida) follows from days 7.5-11, and finally rapid elongation is noticed on day 12 of pregnancy (Assis Neto et al., 2010; Peippo et al., 2011). The trophoblast of day 15 initiates the process of maternal recognition of pregnancy by secreting interferon tau (IFN $\tau$; Roberts 1989). During the process of elongation, the trophoblast changes from a spherical to ovoid shape and transitions to a filamentous form. On day 19 of pregnancy, apposition between the trophoblast and uterine epithelium begins. The epithelial layers start to adhere by interdigitation of the microvilli from days 21-22 approximately (King et al., 1980) and this continues for 1-2 weeks (Guillomot, 1995). Attachment is initiated by flat apposition between trophoblast and glandular uterine epithelium. Placentomes form on preformed caruncles which trigger the trophoblast into mutual proliferation. The trophoblast in the placentome is referred as placentomal trophoblast (Wooding and Burton, 2008) or simply cotyledons. In the interplacentomal areas openings of endometrial glands are observed. The endometrial gland openings are covered by domes of phagocytic trophoblast which facilitate histotrophic uptake of endometrial gland secretions by small endocytotic vesicles or much larger phagocytotic vacuoles since the trophoblast of this area has high phagocytic activity (Wooding and Burton, 2008). Function of trophoblast is manifested from the time of attachment until parturition (Wooding and Wathes, 1980).

Although the trophoblast has a single cell lineage, it is important to point out that, in ruminants, cellular transformation and differentiation result in more than one type of cell (Igwebuike, 2006). The uninucleate trophoblast cells (UTC) proliferate and differentiate into either mature UTC or into binucleate trophoblastic giant cells (BTC; Wooding and Wathes, 1980). The BTC are one of the most characteristic elements of the ruminant placenta. The BTC form a structurally separate population among UTC, arising from UTC by karyokinessis without subsequent cytokinesis. The BTC are characterized by their development of a large population of membranebounded granules, and in probably $97 \%$ of cases, two nuclei (Bjorkman, 1968). They may also undergo endoreduplication, with a resultant DNA content that can be as high as $32 \mathrm{~N}$ (Klisch et al., 1999). In general, the BTC migrate and modify the uterine epithelium by apical fusion to form fetomaternal hybrid syncytial plaques, with up to eight nuclei at the junction of fetal and maternal tissue. In cattle BTC migrate to fuse with apposed uterine epithelium to produce a transient trinucleate cellular layer (minisyncytium) at the interface with the endometrium. In the process of fusion, the full complement of BTC is released into maternal circulation. These syncytial plaques are replaced by regrowth of uterine epithelial cells by day
40 and subsequently BTC and uterine epithelium fusion produce only transient trinucleate minisyncytium throughout the remainder of pregnancy (Wooding and Burton, 2008). The UTC are involved in resorbing minisyncytium after their death, a process maintained all throughout pregnancy.

\section{Sheep and goat}

The embryo enters the uterus from days 4-5 post ovulation, transforms to a blastocyst, loses its zona pellucida and expands in size two to three times (Gaviria and Hernandez, 1994; Igwebuike, 2009; Grazul-Bilska et al., 2013). In these species, the spherical embryo comes to rest in a predictable region in the uterus, presumably as a result of myometrial contractions, and immobilizes itself by growth of trophoblast papillae down the endometrial glands. In sheep, these multicellular papillae were observed only from days 13 to 18 and not at or after day 20 (Wooding et al., 1982). The trophoblast secretion of interferon tau $(\mathrm{IFN} \tau)$ is important in maternal recognition of pregnancy to maintain progesterone secretion by prolonging the lifespan of corpus luteum (Dorniak et al., 2013). At day 16 post ovulation, the trophoblast and the uterine epithelium are closely adherent over the central region of the embryo and developed microvillar interdigitation.

Similar to cattle the sheep and goat trophoblasts have UTC and BTC (Wooding et al., 1993) and undergo structural modifications. The apical microvilli of the trophectoderm interdigitate with a layer consisting of syncytial plaques of limited areas bounding the maternal connective tissue. Throughout pregnancy the BTC migrate to and fuse with the uterine epithelium or its derivatives to form syncytial plaques, which constitute a persistent fetomaternal tissue. The BTC show ultrastructural features which may be correlated in temporal order, with the secretion of steroid hormones, the production of ovine placental lactogen and placental growth hormone (not secreted in cattle), and with the performance of normal nonendocrine placental activities (Soares, 2004).

\section{Pig}

In general, pig embryos enter the uterus between the four- to eight-cell stages approximately 46 $\mathrm{h}$ after ovulation (Hunter, 1974) and have a spherical $100 \mu \mathrm{m}$ blastocyst within the zona pellucida. By approximately day 7 after zona hatching, the embryos migrate and space themselves throughout the uterus and elongate over the next few days through morphologic changes that transform them from spherical to filamentous. Historically, the morphological aspects of placentation in the pig have been well described earlier (Heuser, 1927) and more recently (Kridli et al., 2016). Elongation occurs primarily as a result of hypertrophy of the endoderm and trophectoderm. During elongation, the initial attachment process begins around day 12 .

To signal their presence to the dam, pig conceptuses begin to secrete estrogen around days 11-12 
(Geisert et al., 1990). Estrogen, as a maternal recognition signal of pregnancy, helps in maintaining luteal progesterone secretion by preventing prostaglandin $\mathrm{F} 2 \alpha(\mathrm{PGF} 2 \alpha)$-induced $\mathrm{CL}$ regression. A second estrogen surge between days 14 to 18 is required for CL maintenance beyond day 25 .

Although the pig trophoblast possesses invasive properties, placentation is noninvasive (true epitheliochorial) such that the uterine luminal epithelium remains intact throughout pregnancy. To help prevent premature attachment, microvilli of the porcine uterine epithelium are covered with a thick layer of carbohydrate (glycocalyx), which also thinly covers the fetal epithelium. After the loss of the anti-adhesive properties of glycocalyx from the uterine epithelium, the embryos loosely attach to the endometrium.

Based on electron microscopy, the early morphological stages of placentation in the pig have been reported (Dantzer, 1985). By days 13 to 14 , protruding epithelial proliferations of the uterine epithelium enclosed by chorionic caps immobilize the blastocyst. By day 14, there is close apposition between the apical plasma membranes from trophoblastic and uterine epithelium which may be facilitated by osteopontin, an extracellular matrix protein, that binds to receptors on the trophectoderm and uterine epithelium to form a firm attachment (Erikson et al., 2009). By days 15 to 16 , interdigitating microvilli develop between the apical domes of the uterine epithelium and the trophoblast covering the entire placenta except the openings of the uterine glands. By days 15 to 20 , formation of apical domes on the uterine epithelium closely related to the trophoblast provided with long cytoplasmic extensions into a luminal space between the apical domes, which may be representative of the transition from histiotropic to hemotrophic nutrition (Dantzer, 1985). It has been suggested angiogenic cytokines of the trophoblasts are necessary for the initiation of the growth of the maternal capillary networks noticed around day 16 (Croy et al., 2006). By days 26 to 30 of pregnancy, the non-invasive epitheliochorial placenta is completely established.

The trophoblast and uterine epithelium are partially separated by the secretion of uterine gland milk. Along the uterine gland openings, simple structures called areolae develop in association with each conceptus, which increase during gestation until approximately day 70 (Olio et al., 2014). Areolae are characteristic of epitheliochorial placentas and in pigs large numbers of these are present. Areolae are characterized by having columnar trophoblast caps capable of absorbing and breaking down nutrients. There are changes in the distance between the capillary networks due to the increase in the number of areolae. In pigs, uteroferrin is secreted by uterine glands, absorbed through the areolae, transported to fetal liver, and used for hemoglobin synthesis in fetal erythrocytes. Unlike placental weight, size, and surface area, which increase substantially between Days 20-30 days of gestation and plateau around days 60-70 of gestation, capillary bed volume continues to grow until parturition because of continuous angiogenesis (Bazer et al., 2012).
As in other species, various hormonal and immunerelated factors play a role in placentation in the pig as described in subsequent sections that can have clinical implications.

Horse

The embryo enters the uterus on day 6 after ovulation as a late morula or early blastula (Betteridge et al., 1982; Stout et al., 2005). Complete blastulation results in the formation of blastocoel, a fluid filled cavity, and outer layer of the trophoblast. Trophoblast starts secreting large quantities of mucin-like glycoproteins forming a gelatinous capsule sandwiched between zona pellucida and embryo and the capsule persists for next nearly three weeks (Betteridge et al., 1982; Oriol et al., 1993; Stout et al., 2005). Constant self-induced mobility of the embryo throughout the uterine lumen by its secretions of prostaglandins prior to fixation is unique and the mobility is further aided by the capsule. The endometrial secretory histotroph from the glands provides nourishment to the unimplanted conceptus through overlying trophoblast. The histotroph continues to be secreted throughout pregnancy and is taken up by areolae between microcotyledons (described later). In order to maximize the uptake of the endometrial glandular secretions, the trophoblast in apposition of the endometrial glands forms elongated and pseudostratified cellular structures. The secretions are further transported through the dense capillary beds to the blood vessels of the allantois. In a recent study (Waelchli et al., 2013) on twin embryos, the capsule seemed to be involved in forming adhesion between twins and thus having a role in embryo reduction. The signs of adhesions were found on the capsules in embryos from unilateral twin pregnancies at stages before and during fixation, which became stronger after fixation and included adverse effects on vitelline circulation and/or degeneration of one twin. In addition, limited movement of the yolk sac within the capsule was thought to be essential for maintenance of pregnancy in mares. In the two surviving pairs of embryos, attachment between twins was near the trilaminar/bilaminar yolk sac wall border, which maintained a functional vitelline circulation.

At day 35, the trophoblast proliferates into its invasive and non-invasive components. The former, distinguished as the thickened annulate 'chorionic girdle' invades the endometrium to form the endometrial cups by about days 40 to 42 (Antczak et al., 2013). These are temporary endocrine structures, responsible for secretion of equine chorionic gonadotropin to maintain pregnancy during the first trimester of gestation. A maternal immunological boundary is formed around the invasive trophoblast by the simultaneous collection of lymphocytes and leucocytes around them resulting in spherical cup-like structures, the endometrial cups (Antczak et al., 2013). The endometrial cups last until about days 120-150 of gestation. The non-invasive trophoblast establishes a stable microvillous contact with the endometrial epithelium (Samuel et al., 1974) around day 40 and, 
over the next 100 days, develops a complex multibranched interdigitation with the endometrium, which essentially increases the functional placental area manifold. Although the chorioallantois in mares appears to have a uniform structure, the chorionic surface is actually composed of numerous 1-2 mm size polygonal structures called microcotyledons (Samuel et al., 1974). The microcotyledons constitute the fundamental unit of the fetal-maternal interface in the equine placenta. These microcotyledons are clusters of highly vascularized chorionic villi, which interdigitate with invaginations of the endometrium. The microcotyledonary areas of the placenta allow efficient transfer of small molecules between fetal and maternal blood.

The fetal and endometrial interaction and interdigitation continues and increasingly forms branches and sub-branches of the chorionic villi and endometrial epithelium (Steven, 1982). The area of apposition between trophoblast and endometrial epithelium is maximized by this sub-branching thus maximizing the blood and nutrient exchange between the dam and fetus. There is also a gradual decrease in separation between maternal and fetal blood capillaries during placental development, which is vital for facilitating gas and nutrient exchange. The supply of the endometrial gland secretion and histotroph also continues to remain available as the histotrophabsorbing areas or areolae between the microcotyledons remain functional.

\section{Camel}

The embryo enters the uterus on day 6.5 after ovulation (Anouassi and Tibary, 2013). On day 14 post ovulation, the trophoblast appears as a thin layer of epithelial cells on the surface of the embryo (Tibary, 2001). The process of trophoblast and endometrial epithelial attachment occurs in three phases: precontact, apposition, and adhesion (Abd-Elnaeim et al., 1999). In the precontact phase, the mononuclear trophoblast cells appear separated from the endometrial epithelium by a gap containing interareolar histotroph. Both trophoblast and endometrial epithelium develop apical ectoplasmic pads and microvilli in this gap without establishing contact with each other microvilli (Skidmore et al., 1996). During the apposition phase that is noted by day 25 post ovulation, the microvilli of the trophoblast and endometrial epithelium contact focally. Occasionally, characteristic giant cells several times the size of their uninucleate trophectodermal neighbors develop (Klisch et al., 2005). Serial sections of trophoblast revealed that these giant cells are truly multinucleate with several highly lobulated nuclei and develop due to mitotic polyploidization. These giant cells secrete steroids and are present from about day 35 post conception until parturition. Steroids are secreted by uninucleate trophoblast cells between implantation and formation of giant cells. Previously, giant cells were thought not to possess any secretory functions (Skidmore et al., 1996). However, now it is known that giant cells are the only cells secreting steroids in camel trophoblast after they differentiate (Wooding et al., 2003). In the adhesion phase, the contact between trophoblast and endometrial epithelium increases by mutual growth of the area of apposition and by increase in interdigitation of trophoblast microvilli with that of uterine epithelium as they become anchored to each other (Abd-Elnaeim et al., 1999). The adhesion process starts around day 35 post ovulation and ends around day 56 post ovulation. During this phase the microvillar junction between the trophoblast and the endometrial epithelium become more uniform with feto-maternal interdigitating microvilli growing longer which increases the surface area between fetal and maternal tissues. By day 56 post ovulation, the trophoblast cells become somewhat cuboidal and large multi-nucleated syncytium appears along the trophoblast layers (Skidmore et al., 1996).

$\operatorname{Dog}$

The embryo arrives in the uterus between the 16-cell morula to early blastocyst stage from days 6 to 8 after coitus (Andersen, 1927; Holst and Phemister, 1971 ) or from days 11 to 13 after ovulation (Concannon et al., 2001; Reynaud et al., 2006). Following intrauterine migration of embryos, implantation begins by day 13. Development of placenta in the dog has been well characterized and described (Kehrer, 1973). In general, the zonary endotheliochorial type placenta in the dog is morphologically similar to that of many other species of Canidae (Barrau et al., 1975). It is characterized by a ring-shaped central zone of villous tissue with marginal hematomas and membranes protruding on both sides of this ring that runs circumferentially in the entire diameter of the uterine horns. The outer most tissue layer of the placenta, the chorion, is composed of a trophectoderm externally and mesoderm internally. In general, the trophectoderm gives rise to uninucleated cytotrophoblasts and multinucleated syncytiotrophoblasts (Barrau et al., 1975). Cytotrophoblasts are the primary trophoblast lineage that proliferates and differentiates to form syncytiotrophoblasts (Barrau et al., 1975). While both lineages appear to have degradative and absorptive capabilities, only syncytiotrophoblasts have invasive capabilities in the dog (Barrau et al., 1975). As classically described (Barrau et al., 1975) trophoblastic syncytium is formed and invades between cells of the uterine luminal epithelium by about day 13 . Thereafter, the syncytium continues to spread along the uterine lumen as trophoblastic villi, consisting of cores of cytotrophoblast covered by a continuous layer of syncytium that penetrates deep into the endometrium. The syncytium spread to surround maternal vessels and decidual cells. By about day 26, the trophoblast has extended down to the large lacunae where syncytial trophoblast covering tips of the villi have degenerated, leaving cytotrophoblast exposed to the necrotic zone. Hematomas are subsequently formed by focal necrosis of fetal and endometrial tissue at the poles of the implantation sites. Large pools of extravasated blood accumulate and red blood cells are phagocytized by 
surrounding cytotrophoblasts. In the necrotic zone and hematomas, trophoblast cells may have lost the syncytial covering, but elsewhere maternal vessels and decidual cells in the placenta are in direct contact only with syncytial trophoblast. Comparative details of modifications for histotrophic nutrition have been reviewed (Enders and Carter, 2006).

Many factors have been shown or suspected to be involved in the regulation of trophoblast migration, invasion, and proliferation in carnivores including endopeptidases and their inhibitors, cytokines, growth factors, hormones, and other factors (Kovacs and Ojeda, 2012), which are reviewed in subsequent sections. The clinical importance of these factors are also discussed in association with alter trophoblast invasion (e.g. subinvolution of placental sites, SIPS) and pregnancy loss in dogs.

Cat

The embryos enter the uterus from days 4 to 6 after ovulation in their blastocyst stage. They establish even spacing between them by day 8 post ovulation at which time they are sufficiently large to distend the uterus. Blastocysts hatch from the zona pellucida on day 11 and implantation occurs from days 12 to 13 (Tsutsui and Stabenfeldt, 1993) following transuterine migration (Tsutsui et al., 1989). Some prefer to identify the prehatching phase as the primitive phase and the subsequent phase as the pre-contact phase, the two phases of pre-implantation period (Leiser and Koob, 1993). These researchers also have classified the implantation period into three phases: apposition phase, adhesion phase, and intrusion phase. Cellular contact and interdigitation of microvilli between trophoblast and uterine epithelium starts around this time. Trophoblast divides and produces a syncytium inextricably that is enmeshed with uterine epithelium. The trophoblast is actively phagocytic, capable of displacing and replacing the uterine epithelium and its basement membrane. It then flows around the maternal capillaries and establishes the endotheliochorial pattern of the interhaemal membrane. Angiogenic stimuli provided by the release of factors by the trophoblast help in the growth of villi and remodeling of the connective tissue. The trophoblast loosely appose over the numerous endometrial glands outside the central zone. A characteristic large hemophagous zone develops at the edge or in the middle of zonary area and the trophoblast instigates transient rupture of the maternal blood vessel in the hemophagous zone, comparable to that in the dog. High columnar cells of the trophoblast are involved in active phagocytosis and digestion of red blood cells from the stagnant pool of blood at the fetomaternal interface.

\section{Trophoblast functional roles}

Although much remains to be characterized in different species, a current understanding of the functional role of the trophoblast is important from the perspective of improving reproductive efficiency in animals. Four known major areas for which information is available will be addressed: 1) the role of trophoblast in maternal recognition, 2) prevention of maternal rejection of the embryo, 3) expression of molecular regulators that help in development and apposition/invasion with/into endometrium depending on the species, and 4) the role in the shedding of fetal membranes, an area of economic importance in production animals and life-threatening issue in companion animals, that is least understood in animals other than cattle.

\section{Maternal recognition of pregnancy}

One of the major functions of trophoblast is to prevent the demise of the corpus luteum of the estrous cycle and extend its life into the period of pregnancy. A process referred as 'maternal recognition of pregnancy' (Geisert et al., 2015). In cattle, the UTC are involved in the production of interferon-tau (IFN $\tau$ ) by days 17 to 24 embryo (Roberts et al., 1992) that prevents luteolysis thereby extending the life of corpus lutem of estrous cycle into pregnancy. Other hormones produced by these cells may be involved in the process of maternal recognition. For example, the UTC and BTC express enzymes needed for production of estrogens (mainly conjugated) and produce small amount of progesterone from days 150 to 240 of pregnancy (Schuler et al., 2008). The BTC produce placental lactogen (Wooding and Beckers, 1987; Wooding, 1992; Nakano et al., 2002) and other hormones such as progesterone (Reimers et al., 1985), estrogens, prostaglandins (Gross and Williams, 1988; Schuler et al., 2006).

In horses, a well-recognized conceptus derived signal for maternal recognition of pregnancy has not been reported (Klein and Troedsson, 2011a; Aurich and Budik, 2015). The earliest indication of maternal recognition is that only the fertilized embryos enter into the uterus while as unfertilized oocyte is retained in the oviduct. The differential transport of embryo and unfertilized eggs is ascribed to secretion of PGF2 $\alpha$ and prostaglandin E2 (PGE2) by the morula/early blastocyst stage embryo which facilitates its movement from the oviduct to the uterus (Weber et al., 1991; Betteridge, 2000). Therefore, the embryonic cells that have started to differentiate into trophoblast play an important role even at the early stages of the development. In the uterus, the tough gelatinous capsule secreted by the trophoblast between days 6-22 makes it impossible for the equine embryo to elongate between days 10 to 14 as it does in ruminants. As a result, the early embryo remains spherical and the trophoblast does not come in close contact with a sizeable area of endometrium. However, the embryo moves continuously throughout the uterine lumen before fixation and implantation at around days 20-22 (Ginther, 1985) and this continuous movement helps in exerting the antiluteolytic effect on the uterus thus preventing the cyclic secretion of uterine PGF $2 \alpha$ and helping in maintaining the pregnancy (Allen and Wilsher, 2009). The inhibition of PGF2 $\alpha$ has been attributed to the reduced expression of cyclooxygenase2 and has been suggested to be a target of conceptus 
derived antiluteolytic mechanism in horses (Klein and Troedsson, 2011b). Unlike ruminants, interferon-like molecules as produced by ruminant trophoblast have not been reported from the equine trophoblast. Conceptus derived estrogens and prostaglandins, principally PGE2 have also been postulated as the potential antiluteolytic factors but have not been confirmed experimentally (Wilsher and Allen, 2011; Raheem, 2017). Transcriptional profiling of equine embryos at days 8 , 10,12 , and 14 has indicated a dynamic interaction between the developing early conceptus and endometrial interface that may be critical for recognition and maintenance of pregnancy, and continued progesterone support (Allen and Wilsher, 2009; Klein et al., 2010). A custom designed whole genome microarray showed 355, 1211, and 1144 gene transcripts differentially expressed in embryos at days 10,12 , and 14 , respectively, when compared to day 8 conceptus. Majority of the upregulated transcripts localized to extracellular region indicating a crosstalk between the conceptus and the surrounding endometrial tissue that could occur due to release of gene products into the uterine lumen. Interestingly, protein products of five up-regulated genes $F G A, F G B, F G G, N E U 2$, and $P A I 1$, which were selected for their potential developmental significance were detected and localized to trophoblast cells by immunohistochemistry. The most current concept of maternal recognition of pregnancy in mares revolves around mechanisms occurring from days 12/13 after ovulation (Aurich and Budik, 2015). The mechanisms include the movement of conceptus through the uterine lumen as a result of the action of conceptus-derived prostaglandins on the myometrium, stimulation of conceptus growth by the action of endometrial oxytocin on the oxytocin receptors in the trophoblast, down-regulation of cyclooxygenase 2 in the endometrial epithelium due to altered transcription probably in response to embryonic/trophoblastic signals, and failure of endometrial oxytocin to stimulate endometrial synthesis of PGF2 $\alpha$. More studies are needed to further identify and clarify the trophoblastic mechanisms of maternal recognition of pregnancy in mares.

\section{Prevention of maternal rejection of early embryo}

The trophoblast not only helps in maternal recognition of the presence of the embryo but also prevents its rejection. Maternal immune tolerance against the fetal allograft is regulated by complex mechanisms. These mechanisms involve inhibition of paternally inherited factors like major histocompatibility complex (MHC) antigens by the placenta, systemic immunomodulatory response of the mother and immunomodulatory responses that take place at the local placental level in the uterus. In cattle, UTC express major histocompatibility complex class I (MHC1) and this disappears from the BTC (Bainbridge et al., 2001; Rapacz-Leonard et al., 2014) to avoid maternal rejection. In horses, a unique mechanism of expression of MHC in trophoblast cells is presented with the trophoblasts of allantochorionic not expressing any MHC class 1 proteins, and chorionic girdle trophoblasts and endometrial cups expressing high levels MHC class I proteins of both maternal and paternal origin (Donaldson et al., 1994; Bacon et al., 2002). Around day 30, MHC class I genes expression is ten times higher in chorionic girdle than somatic cells. The expression is similar during the invasion of chorionic girdle into endometrium and is maintained until shortly after the differentiation into endometrial cup trophoblasts and then decreases to undetectable levels from days 45-57 (Crump et al., 1987; Kydd et al., 1991; Maher et al., 1996; Bacon et al., 2002). The chorionic girdle MHC class I proteins induce strong cytotoxic antibody responses in all mares pregnant with histoincompatible fetus (Kydd et al., 1991). Antibodies against paternal MHC class I antigens are detected by day 60 in primiparous mares. MHC class I proteins are also expressed in subpopulations of trophoblast cells in several other species (Noronha and Antczak, 2010).

\section{Expression of molecular regulators}

A successful establishment of pregnancy is absolutely dependent on a biologically viable blastocyst that has the competence to undergo hatching, development of trophoblast, followed by attachment/invasion to the endometrium depending on the species. Each event is important in the life of the early embryo and these events are facilitated/controlled/aided by a series of molecular regulators released by the blastocyst, trophoblast, and endometrium. These include steroid hormones, growth factors, cell adhesion molecules, cytokines, and proteases. While some are expressed by blastocyst, trophoblast, and endometrium, examples of such factors include leukemia inhibitor factor and its receptors, and prolactin receptors in dogs (Kowalewski et al., 2011), others are specific to each one of these structures. For example in pigs, peak IL1 $\beta$ secretion by the blastocyst (Ross et al., 2003), results in remarkable rapid changes in cell shape and size. The blasocyst from its original sphere shape remodels into a $100 \mathrm{~mm}$ thin filament by day 13 post ovulation. The rapid mitotic rate resumes and within 4 days the filament reach up to $1 \mathrm{~m}$ long. The angiogenic cytokines produced by the trophoblast contribute to the initiation of the growth of the maternal capillary net which starts at day16 post ovulation and soon after the trophoblast proliferates over the glandular portion of the endometrial glands. In horses, interleukin (IL)-22, an immunomodulatory cytokine, is expressed by invasive chorionic girdle (Brosnahan et al., 2012). Bone morphogenetic protein 4 is believed to regulate the terminal differentiation of chorionic girdle acting paracrinally from chorion, allantochorion and yolk sac through the Sma-and Mad-related protein, a mechanism of signaling by TGF $\beta$ superfamily proteins (CabreraSharp et al., 2014). Similarly in dogs, many factors have been shown or suspected to be involved in the regulation of trophoblast migration, invasion, and proliferation in carnivores including endopeptidases and their inhibitors, cytokines, growth factors, hormones, and other factors (Kovacs and Ojeda, 2012). Cytokine 
expression of interleukins, IL-1 $\beta$, IL- 6 and IL- 8 , has been detected in pre-implantation embryos of dogs (Van Mourik et al., 2009). Matrix-metalloproteinases (MMPs) and their respective tissue inhibitors of metalloproteinases (TIMPs) have been detected in the canine trophoblast (Sahlfeld et al., 2012) and endometrium (Beceriklisoy et al., 2007). The expression of MMP-2 and MMP-9 peaked at the time of implantation with more MMP-2 than MMP-9 (Beceriklisoy et al., 2007). Reportedly (Staun-Ram and Shalev, 2005), the MMP-TIMP interaction controls trophoblast invasion by restricting over or underinvasion into the uterus. In support of this concept, immunohistochemical expression of MMP-2, MMP-9 and TIMP-2 have been detected in isolated canine trophoblast of term placenta (Sahlfeld et al., 2012). Temporally, from pre-parturition to parturition, there appears to be an increase in TIMP-2 mRNA expression as pregnancy advances. Regardless of the differences and timing of expression factors, they are critical in trophoblast invasion and implantation. It is important to have much more research conducted in this area.

\section{Expulsion of fetal membranes}

The MHC class I expression in bovine trophoblast and their tight regulation are biologically relevant. Early in pregnancy, a complete shutdown of major MHC class I expression by trophoblast appears to be critical for normal placental development and fetal survival. This immunological camouflage is vital to avoid recognition by the multifactorial array of cellular and hormonal mechanisms that mediate rejection. However, the trophoblast cells in cows, express MHC class 1 antigens only in the interplacentomal areas from six months onwards with a profound expression in the near-term placenta (Bainbridge et al., 2001). So, in a mature placenta, maternal immunological recognition of fetal MHC class I proteins triggers an immune and inflammatory responses that contribute to rejection of fetal membranes at parturition. It is interesting to note that in these situations there is a clear adaptation of the immune system for a function distinct from protection against pathogens. In summary, as pointed out in recent reviews (McNaughton and Murray, 2009; Benedictus et al., 2015; Mordak and Stewart, 2015; Attupuram et al., 2016), MHC compatibility and expression of MHC class 1 antigen by the trophoblasts has significant molecular consequences in controlling the expulsion the incidence of retention of fetal membranes. Addressing and remedying this particular issue scientifically can reduce the economic loss in production animals due to this condition and may help to address this issue in companion animals wherein it is a life threatening issue, if veterinary treatment is not provided.

\section{Trophoblast factors of clinical relevance}

Four factors connected with trophoblast in the diagnosis of pregnancy will be discussed: 1) pregnancy associated glycoproteins in cattle, 2) equine chorionic gonadotropin in horses, 3) acute phase proteins in dogs and 4) relaxin in dogs.

\section{Pregnancy associated glycoprotein}

Expression of glycoproteins (Zoli et al., 1992; Green et al., 2000; Wooding et al., 2005) have clinical relevance, particularly, in pregnancy diagnosis. Measurement of pregnancy-associated glycoproteins (PAGs) in circulation in cattle is used as a biochemical marker of pregnancy because certain quantities are released into maternal circulation. The BTC are the only source of PAG and can be detected in maternal circulation of pregnant cows from days 28-30 of pregnancy (concentrations $>0.5-0.8 \mathrm{ng} / \mathrm{ml}$, with 0.8 $\mathrm{ng} / \mathrm{ml}$ constituting the threshold for positive pregnancy diagnosis). At this time, the practical or routine use of PAG measurement to predict or diagnose pregnancy loss is limited by assay variability (depending on antibody used and specific PAGs- detected) and protracted half-lives of PAGs following pregnancy loss). As more specific assays designed to detect particular classes or individual PAGs become available, PAGs may become more widely and routinely used for diagnosing pregnancy wastage in cattle. However, their absence in the circulation on days 28-30 after breeding in cattle can be used as a means to establish nonpregnancy (Whitlock and Maxwell, 2008).

In pregnant ewes and goats, PAG can be detected from days 22-26 after breeding (Ranilla et al., 1994; Sousa et al., 1999). In these species, PAG profiles are quite different from those obtained in cattle. Concentrations increase faster from week 3 to 4 , reaching higher levels during the first month of pregnancy (up to $20 \mathrm{ng} / \mathrm{ml}$ ). Different variants of PAG have been reported in horse (Green et al., 1999), camel (Majewska et al., 2009), and pig (Szafrañska and Panasiewicz, 2002).

Recently, presence of a family of pregnancyspecific glycoproteins (PSGs) in horses was reported (Aleksic et al., 2016). These proteins are members of carcinoembryonic antigen cell adhesion molecule (CEACAM) family that are secreted by trophoblast cells of rodents and primates and have been identified in horses (Aleksic et al., 2016). Seven genes that encode secreted PSG-like CEACAMs have been identified in horse trophoblast cells from chorionic girdle and endometrial cups. Chorionic girdle cells are highly invasive cells and in endometrial cups are in close proximity of maternal immune system. Thus, invasive trophoblast cells share the micoenvironment of the trophoblast cells of primates and rodents. Some equine PSGs exhibit similar activity to certain rodent and human PSGs in functional assay of platelet-fibrinogen binding. PSGs are thought to modulate immune, angiogenic and platelet responses during pregnancy. Further studies of PSGs in horse are suggested to explore their functions in maternal-fetal interactions.

\section{Equine chorionic gonadotropin}

A hormone of considerable importance and unique to horses is synthesized by the endometrial cups 
that are formed after the invasion of chorionic girdle into endometrium as discussed before. In horses, it is primarily luteotrophic supporting secondary corpora lutea during pregnancy while when injected in other species, it has follicular stimulating activity and has been used in superstimulation (superovulation) of ovaries. Its appearance in horses around day 40, peaking around day 80, and declining around day 120 are characteristic and this information is used for the diagnosis of pregnancy in horses (Henderson et al., 1998). Its major application is in other species in superstimulation of ovaries for embryo flushing and has many clinical application (De Rensis and López-Gatius, 2014).

\section{Acute phase proteins}

Although these are not very specific for the trophoblast, production of acute phase protein (APP) by the trophoblast coincides with implantation as an inflammatory response. APP interactions with cytokines is an emerging area of investigation in dogs with the detection of c-reactive protein, haptoglobin, fibrinogen, ceruplasmin, seromucoid, and glycoproteins in the plasma of pregnant bitches from days 28-37 after mating (Evans and Anderton, 1992). Subsequent to induced localized inflammation and increase in APPs in adult beagles, an increase in cytokine IL-6 and tumor necrosis factor (TNF) were detected (Yamashita et al., 1994). The inflammatory response at implantation was followed by an increase in serum C-reactive protein in the dog (Concannon et al., 1996). Although measurement of acute phase proteins has been suggested as a method of pregnancy diagnosis since pregnancy specific increase in circulating concentrations was observed (Eckersall et al., 1993) yet a reliable test is not available notwithstanding further research in this area (Kuribayashi et al., 2003; Ulutas et al., 2009).

\section{Relaxin}

Trophoblast has been identified as the source of relaxin in domestic animals such as mares (Klonisch et al., 1997) and cats (Klonisch et al., 1999). The discussion will focus in dogs because of its clinical application in dogs (Bergfelt et al., 2014). Canine syncytiotrophoblast are the main source of relaxin (Tsutsui and Stewart, 1991). It has been observed that canine cytotrophoblasts surrounding maternal blood vessels also express relaxin-like factor (RLF) mRNA at early to mid-gestation (Klonisch et al., 2001).

Pregnancy specific increases in circulating concentrations of relaxin is used as a diagnostic aid in dogs. A few commercial kits have been developed to give a fast qualitative indication of whether concentrations of relaxin have increased greater than a baseline concentration indicative of pregnancy. Because the embryo/trophoblast and/or fetoplacental unit appears to be a major source of relaxin in dogs, it has been suggested that a decrease in circulating concentrations of relaxin can also be used to detect pregnancy loss
(Günzel-Apel et al., 2006). For details of historic progression and current use of relaxin immunoassays in the dog refer a recent review (Bergfelt et al., 2014).

\section{Pregnancy failures}

\section{Early embryonic loss}

Early embryonic loss is a major limitation to fertility in animals. Despite intense investigation for a number of years, our understanding of the molecular, cellular, and physiological mechanisms associated with the embryonic loss is limited, and the role of trophoblast in this process remains elusive. Trophoblast may have a role to play in the early embryonic death, a condition observed in all animals with higher incidence in cattle. In cattle, it has been estimated that there is $90 \%$ fertilization rate with a loss of $35 \%$ embryos (Diskin et al., 2006). It is important to note that $70-80 \%$ of the embryos are lost before day 16 (Diskin et al., 2006). Much work is needed to document the role of trophoblast and its immune modulation factors/events leading to early embryonic death. One possibility is that the trophoblast IFN $\tau$ is not able to trigger particular downstream signaling pathways of the endometrium, which may contribute to the embryonic loss. It is also possible that trophoblast may respond to stimulation and produce trophoblast-toxic factors that have been suggested as cause for early embryonic death and abortion in women (Hill et al., 1992). In this regard, it has been shown that Brucella abortus modulates the innate immune response by trophoblastic cells, suppressing the expression of proinflammatory mediators during the early stages of infection that is followed by a delayed and mild expression of proinflammatory cytokines (Carvalho Neta et al., 2008). Embryonic loss is documented in other animals. In dogs, it has been documented that pregnancy loss due to resorption was between 11-13\% (Andersen and Simpson, 1973; Robertson et al., 1979) and stillbirth in dogs accounted for 2.2 to $4.5 \%$ incidence rate (Johnston and Raksil, 1987). Embryonic loss is universal and so is the function of trophoblast in the establishment and growth of early embryo; hence remedial measures can be developed, if the details of embryonic wastage that occurs due to immunomodulation of trophoblast is made known.

\section{Abortion}

Regardless of the agents responsible for abortion (infectious and noninfectious causes), in each situation the functional ability (mainly immunological) of the trophoblast is challenged and perturbed prior to abortion. Immunomodulation of trophoblast can occur following the entry of organisms directly into the trophoblast and activating the process of fetal rejection. The pathogenesis of brucellosis exemplifies this method. As early as 1919, the characteristic ability of intracellular localization of Brucella abortus within the trophoblast was described (Smith, 1919). The initial entry of Brucella abortus occurred in the erythro- 
phagocytic part of the trophoblast. This was followed by the spread of Brucella abortus to the cells of the chorioallantoic membrane. After intracellular replication, large numbers of Brucella abortus organisms were found within trophoblast and chorioallantois. It has been shown that trophoblast are the primary cell type involved in the pathogenesis of abortion by brucellosis (Anderson and Cheville, 1986). Further, Brucella abortus organism replicates in the lumen of the rough endoplasmic reticulum of the trophoblast utilizing proteins translocated into the organelle for its own metabolism brucellosis (Anderson and Cheville, 1986). Their multiplication within the trophoblast causes hypertrophy of the rough endoplasmic reticulum and subsequent release into the uterine lumen. Eventually, vasculitis leads to separation of trophoblast and maternal epithelium resulting in death of the fetus and consequent abortion brucellosis (Anderson and Cheville, 1986). Besides Brucella abortus, there may be other similar infectious agents that may induce abortion by destroying the functional ability of trophoblast by their direct entry into trophoblast. For example, in habitually aborting cats, multifocal necrosis started at the trophoblast prior to extension to all the cell of the labyrinth (Huxtable et al., 1979). Apart from direct entry and damage to trophoblast, the second method in the process of pathogenesis of abortion may involve in interfering with the immune function of the trophoblast. Studies on the modification of immune function of trophoblast and its role in abortion remain to be characterized in domestic animals.

\section{Abnormal trophoblast proliferation}

Excessive or insufficient trophoblast invasion occur in animals and humans with attended consequences such as threating or loss of pregnancy. For example, 'hydatidiform mole' that occurs in cattle is characterized by hyperplastic mass of trophoblast with varying degree of trophoblastic proliferation (Corcoran and Murphy, 1965; Gopal et al., 1980, Meinecke et al., 2003; Morris et al., 2008). The term 'hydatidiform' refers to 'like a water cyst' and the term 'mole' refers to 'millstone' since this trophoblastic disease is accompanied by an irregular mass of water-logged placenta with grossly swollen and grape-like chorionic villi. This hydropic transformation of the villous mesenchyme is due to the lack of or maldevelopment of or regression of the villous vasculature, which makes the drainage of fluid supplied by the trophoblast impossible. Interestingly, this developmental anomaly of trophoblast (enormous amount) is accompanied by increased concentrations of PAG in maternal circulation (Sousa et al., 2006).

Subinvolution of placental sites that occur in dogs is another example of excessive trophoblast proliferation. A disorder that causes a failure or delay of normal uterine involution in pregnant and postpartum dogs, especially dogs under 3 years old following a normal delivery (Al-Bassam et al., 1981; Orfanou et al., 2009). Excessive trophoblast invasion and damage to uterine vasculature result in failure of normal endometrial blood vessel thrombus formation causing secondary occlusion and bleeding. Symptoms include a bright red sanguineous discharge that persists in dogs for more than 8 weeks after whelping (Sontas et al., 2015). The diagnosis and treatment is beyond the scope of this review and have been reviewed earlier (Reberg et al., 1992). The condition, if diagnosed promptly, can be treated successfully.

As mentioned earlier, trophoblast has a function in the expulsion of fetal membranes. In certain cases, retention of fetal membranes in animals is believed to be due to abnormal proliferation of trophoblast. Retention of fetal membranes, a clinical condition recognized as retained fetal membranes or commonly as 'retained placenta' has a major economic impact in cattle (Peter, 2013, 2015). Conditions reported in humans such as placenta accrete vera, placenta increta, placenta percreta, choriocarcinoma, and placental site trophoblastic tumor are attributed to excessive proliferation of trophoblast (Gullaba, 2013). The etiology of abnormal trophoblast proliferative activity is not known although a study considered the role of proliferating cell nuclear antigen in women (Jeffers et al., 1994). Each condition listed can lead to maternal morbidity and mortality, although some are more life-threatening than others. These disorders share similar symptomatic presentation and possibly similar etiopathophysiology, suggesting that these trophoblast conditions can be studied using animal models to develop preventative strategies.

In conclusion, regardless of the anatomical differences of the uterus and placentation, the trophoblast plays a similar role in the domestic species. Clearly, trophoblast has roles in acquisition of space for embryo development, in tissue remodeling during implantation and placentation, in defense mechanisms (Bevilacqua et al., 2010), and in shedding of fetal membranes after birth. Hence, this unique cellular activity may be very relevant and critical for the congenial maternal-fetal relationship beyond its nutritional function. However, as discussed, there are certain functional differences of trophoblast between species. For example, the availability of trophoblast markers to monitor trophoblast function is not yet known for all species. Monitoring trophoblast function is not only important to predict embryonic loss but also monitor high risk pregnancies. Hence, any investigation of trophoblastic function requires a longitudinal followup during pregnancy (Sousa et al., 2008) and our ability to monitor its marker. Currently, PAG is probably the best trophoblastic agent available to monitor pregnancy in ruminants, however, there is no single test currently available that immediately differentiates continuing from non-continuing pregnancies. Similarly, trophoblastic products in canine species such as relaxin and acute phase proteins appear to have application not only in pregnancy diagnosis but also in monitoring fetal viability and pending pregnancy loss. Another trophoblastic molecule, equine chorionic gonadotropin, has application in mares in pregnancy diagnosis and its usefulness in monitoring embryo/fetal viability needs 
further work. Thus, there still remains gaps in our understanding of numerous aspects of trophoblast in all species, which clearly warrants further research in this important area.

\section{Conflict of interest}

The authors declare that they have no conflict of interest nor should be perceived as prejudicing the impartiality of research literature in not citing all publications in the review. This article does not contain any studies with human participants or animals performed by the authors.

\section{References}

Abd-EInaeim MM, Pfarrer C, Saber AS, AbouElmagd A, Jones CJ, Leiser R. 1999. Fetomaternal attachment and anchorage inthe early diffuse epitheliochorial placenta of the camel (Camelus dromedarius). Light, transmission, and scanning electron microscopic study. Cells Tissues Organs, 164:141-154.

Al-Bassam MA, Thomson RG, O'Donnell L. 1981. Involution abnormalities in the postpartum 128-uterus of the bitch. Vet Pathol, 18:208-218.

Aleksic D, Blaschke L, Mißbach S, Hänske J, Weiß W, Handler J, Zimmermann W, Cabrera-Sharp V, Read JE, de Mestre AM, O'Riordan R, Moore T, Kammerer R. 2016. Convergent evolution of pregnancy-specific glycoproteins in human and horse. Reproduction, 152:171-184.

Allen WR, Wilsher S. 2009. A review of implantation and early placentation in the mare. Placenta, 30:10051015.

Andersen A, Simpson M. 1973. Introduction. In: Andersen A. The Ovary and Reproductive Cycle of the Dog (Beagle). Los Altos, CA: Geron-X. pp. 11.

Andersen D. 1927. The rate of passage of the mammalian ovum through various portions of the fallopian tube. Am J Physiol, 82:557-569.

Anderson TD, Cheville NF. 1986. Ultrastructural morphometric analysis of Brucella abortus-infected trophoblasts in experimental placentitis. Bacterial replication occurs in rough endoplasmic reticulum. Am J Pathol, 124:226-237.

Anouassi A, Tibary A. 2013. Development of a large commercial camel embryo transfer program: 20 years of scientific research. Anim Reprod Sci, 136:211-221.

Antczak DF, de Mestre AM, Wilsher S, Allen WR. 2013. The equine endometrial cup reaction: a fetomaternal signal of significance. Annu Rev Anim Biosci, 1:419-442.

Assis Neto AC, Pereira FT, Santos TC, Ambrosio CE, Leiser R, Miglino MA. 2010. Morpho-physical recording of bovine conceptus (Bos indicus) and placenta from days 20 to 70 of pregnancy. Reprod Domest Anim, 45:760-772.

Attupuram NM, Kumaresan A, Narayanan K, Kumar H. 2016. Cellular and molecular mechanisms involved in placental separation in the bovine: a review. Mol Reprod Dev, 83:287-297.
Aurich C, Budik S. 2015. Early pregnancy in the horse revisited: does exception prove the rule? J Anim Sci Biotechnol, 6:50. doi: 10.1186/s40104-015-0048-6.

Bacon SJ, Ellis SA, Antczak DF. 2002. Control of expression of major histocompatibility complex genes in horse trophoblast. Biol Reprod, 66:1612-1620.

Bainbridge DR, Sargent IL, Ellis SA. 2001. Increased expression of major histocompatibility complex (MHC) class I transplantation antigens in bovine trophoblast cells before fusion with maternal cells. Reproduction, 122:907-913.

Barrau M, Abel, J, Torbit C, Tietz W. 1975. Development of the implantation chamber in the pregnant bitch. Am J Anat, 143:115-129.

Bazer FW, Song G, Kim J, Dunlap KA, Satterfield MC, Johnson GA, Burghardt RC, Wu G. 2012. Uterine biology in pigs and sheep. $J$ Anim Sci Biotechnol. 3:23. doi: 10.1186/2049-1891-3-23.

Beceriklisoy HB, Walter I, Schäfer-Somi S, Miller I, Kanca H, Izgür H, Aslan S. 2007. Matrix metalloproteinase (MMP)-2 and MMP-9 activity in the canine uterus before and during placentation. Reprod Domest Anim, 42:654-659.

Benedictus L, Koets Ad P, Rutten VPMG. 2015. The role of placental MHC class I expression in immuneassisted separation of the fetal membranes in cattle. $J$ Reprod Immunol, 112:11-19.

Bergfelt DR, Peter AT, Beg MA. 2014. Relaxin: a hormonal aid to diagnose pregnancy status in wild mammalian species. Theriogenology, 82:1187-1198.

Betteridge KJ, Eaglesome MD, Mitchell D, Flood PF, Beriault R. 1982. Development of horse embryos up to twenty two days after ovulation: observations on fresh specimens. J Anat, 135:191-209.

Betteridge KJ. 2000. Comparative aspects of equine embryonic development. Anim Reprod Sci, 60/61:691702.

Bevilacqua E, Hoshida MS, Amarante-Paffaro A, Albieri-Borges A, Zago Gomes S. 2010. Trophoblast phagocytic program: roles in different placental systems. Int J Dev Biol, 54:495-505.

Bjorkman NH. 1968. Fine structure of cryptal and trophoblastic giant cells in the bovine placentome. $J$ Ultrastruct Res, 24:249-258.

Brosnahan MM, Miller DC, Adams M, Antczak DF. 2012. IL-22 is expressed by the invasive trophoblast of the equine (Equus caballus) chorionic girdle. $J$ Immunol, 188:4181-4187.

Cabrera-Sharp V, Read JE, Richardson S, Kowalski AA, Antczak DF, Cartwright JE, Mukherjee A, de Mestre AM. 2014. SMAD1/5 signaling in the early equine placenta regulates trophoblast differentiation and chorionic gonadotropin secretion. Endocrinology, 155:3054-3064.

Carter AM, Enders AC. 2004. Comparative aspects of trophoblast development and placentation. Reprod Biol Endocrinol, 2:46. doi:10.1186/1477-7827-2-46.

Carter AM, Enders AC. 2013. The evolution of epitheliochorial placentation. Annu Rev Anim Biosci, 1:443-467.

Carter AM, Mess AM. 2017. The evolution of fetal membranes and placentation in carnivores and ungulates 
(Ferungulata). Anim Reprod, 14:124-135.

Carvalho Neta AV, Stynen AP, Paixão TA, Miranda KL, Silva FL, Roux CM. Tsolis RM, Everts RE, Lewin HA, Adams LG, Carvalho AF, Lage AP, Santos RL. 2008. Modulation of the bovine trophoblastic innate immune response by Brucella abortus. Infect Immun, 76:1897-1907.

Concannon PW, Gimpel T, Newton L, Castracane VD. 1996. Postimplantation increase in plasma fibrinogen concentration with increase in relaxin concentration in pregnant dogs. Am J Vet Res, 57:13821385.

Concannon PW, Tsutsui T, Shille V. 2001. Embryo development, hormonal requirements and maternal responses during canine pregnancy. $J$ Reprod Fertil, 57:169-179.

Corcoran CJ, Murphy EC. 1965. Rare bovine placental tumour--a case report. Vet Rec, 77:1234-1235.

Cross JC, Werb Z, Fisher SJ. 1994. Implantation and the placenta: key pieces of the development puzzle. Science, 266:1508-1518.

Croy BA, van den Heuvel MJ, Borzychowski AM, Tayade C. 2006. Uterine natural killer cells: a specialized differentiation regulated by ovarian hormones. Immunol Rev, 214:161-185.

Crump A, Donaldson WL, Miller J, Kydd JH, Allen WR, Antczak DF. 1987. Expression of major histocompatibility complex (MHC) antigens on horse trophoblast. J Reprod Fertil, 35:379-388.

Dantzer V. 1985. Electron microscopy of the initial stages of placentation in the pig. Anat Embryol, 172:281-293.

De Rensis F, López-Gatius F. 2014. Use of equine chorionic gonadotropin to control reproduction of the dairy cow. A review. Reprod Domest Anim, 49:177-182. Diskin MG, Murphy JJ, Sreenan JM. 2006. Embryo survival in dairy cows managed under pastoral conditions. Anim Reprod Sci, 96:297-311.

Donaldson WL, Oriol JG, Pelkaus CL, Antczak DF. 1994. Paternal and maternal major histocompatibility complex class I antigens are expressed co-dominantly by equine trophoblast. Placenta, 15:123-135.

Dorniak P, Bazer FW, Spencer TE. 2013. Physiology and Endocrinology Symposium: Biological role of interferon tau in endometrial function and conceptus elongation. J Anim Sci, 91:1627-1638

Eckersall PD, Harvey MJ, Ferguson JM, Renton JP, Nickson DA, Boyd JS. 1993. Acute phase proteins in canine pregnancy (Canis familiaris). $J$ Reprod Fertil, 47:159-164.

Enders AC, Carter AM. $2006 . \quad$ Comparative placentation: some interesting modifications for histotrophic nutrition. A review. Placenta, 27(suppl. A):S11-16.

Erikson DW, Burghardt RC, Bayless KJ, Johnson GA. 2009. Secreted phosphoprotein 1 (SPP1, osteopontin) binds to integrin alpha $\mathrm{v}$ beta 6 on porcine trophectoderm cells and integrin alpha $\mathrm{v}$ beta 3 on uterine luminal epithelial cells, and promotes trophectoderm cell adhesion and migration. Biol Reprod, 81:814-825

Evans J. Anderton D. 1992. Pregnancy diagnosis in the bitch: the development of a test based on the measurement of acute phase proteins in the blood. Ann Zootech, 41:397-405.

Gaviria MT, Hernandez A. 1994. Morphometry of implantation in sheep. I. Trophoblast attachment, modification of the uterine lining, conceptus size and embryo location. Theriogenology, 41:1139-1149.

Geisert RD, Zavy MT, Moffatt RJ, Blair RM, Yellin T. 1990. Embryonic steroids and the establishment of pregnancy in pigs. $J$ Reprod Fertil, 40:293-305.

Geisert RD, Johnson GA, Burghardt RC. 2015. Implantation and establishment of pregnancy in the pig. In: Geisert RD, Bazer FW (Ed.). Regulation of Implantation and Establishment of Pregnancy in Mammals. NewYork, NY: Springer. pp. 137-163. (Adv Anat Embryol Cell Biol, 216).

Ginther OJ. 1985. Dynamic physical interactions between the equine embryo and uterus. Equine Vet $J$, 17(suppl. 3):41-47.

Gopal T, Leipold $\quad$ HW, Dennis $\quad$ SM. 1980. Hydatidiform moles in Holstein cattle. Vet Rec, 107:395-397.

Grazul-Bilska AT, Johnson ML, Borowicz PP, Baranko L, Redmer DA, Reynolds LP. 2013. Placental development during early pregnancy in sheep: Effects of embryo origin on fetal and placental growth and global methylation. Theriogenology, 79:94-102.

Green JA, Xie S, Szafranska B, Gan X, Szafranska B, Newman AG. McDowell K, Roberts RM. 1999. Identification of a new aspartic proteinase expressed by the outer chorionic cell layer of the equine placenta. Biol Reprod, 60:1069-1077.

Green JA, Xie S, Quan X, Bao B, Gan X, Mathialagan N. Beckers JF, Roberts RM. 2000. Pregnancy-associated bovine and ovine glycoproteins exhibit spatially and temporally distinct expression patterns during pregnancy. Biol Reprod, 62:1624-1631.

Gross TS, Williams WF. 1998. Bovine placental prostaglandin synthesis: principal cell synthesis as modulated by the binucleate cell. Biol Reprod, 38:10271034.

Gullaba JM. 2013. Role of IL-8 and TIMP-2 on term canine trophoblast migration, invasion, and proliferation. Corvallis, OR: Oregon State University. Master Thesis.

Guillomot M. 1995. Cellular interactions during implantation in domestic ruminants. J Reprod Fertil, 49:39-51

Günzel-Apel AR, Zabel S, Bunck CF, Dieleman SJ, Einspanier A, Hoppen HO. 2006. Concentrations of progesterone, prolactin and relaxin in the luteal phase and pregnancy in normal and short-cycling German Shepherd dogs. Theriogenology, 66:1431-1435.

Hall V, Hinrichs K, Lazzari G, Betts DH, Hyttel P. 2013. Early embryonic development, assisted reproductive technologies, and pluripotent stem cell biology in domestic mammals. Vet J, 197:128-142

Henderson K, Stevens S, Bailey C, Hall G, Stewart J, Wards R. 1998. Comparison of the merits of measuring equine chorionic gonadotrophin (eCG) and blood and faecal concentrations of oestrone sulphate for 
determining the pregnancy status of miniature horses. Reprod Fertil Dev, 10:441-444.

Heuser CH. 1927. A study of the implantation of the ovum of the pig from the stage of the bilaminar blastocyst to the completion of the fetal membranes. Carnegie Contrib Embryol, 19:229-243.

Hill JA, Polgar K, Harlow BL, Anderson DJ. 1992. Evidence of embryo- and trophoblast-toxic cellular immune response(s) in women with recurrent spontaneous abortion. Am J Obstet Gynecol, 166:10441052.

Holst PA, Phemister RD. 1971.The prenatal development of the dog: preimplantation events. Biol of Reprod, 5:194-206.

Hubrecht AAW. 1889. The placentation of Erinaceus Europaeus with remarks on the phylogeny of the placenta. Quart J Microsc Sci, 30:283-404.

Hunter RH. 1974. Chronological and cytological details of fertilization and early embryonic development in the domestic pig, Sus scrofa. Anat Rec, 178:169-185.

Huxtable CR, Duff BC, Bennett AM, Love DN, Butcher DR. 1979. Placental lesions in habitually aborting cats. Vet Pathol, 16:283-289.

Igwebuike UM. 2006. Trophoblast cells of ruminant placentas: a minireview. Anim Reprod Sci. 93:185-98.

Igwebuike UM. 2009. A review of uterine structural modifications that influence conceptus implantation and development in sheep and goats. Anim Reprod Sci. 112:1-7. doi: 10.1016/j.anireprosci.2008.

Jeffers MD, Grehan D, Gillan JE. 1994. Comparison of villous trophoblast proliferation rate in hydatidiform mole and non-molar abortion by assessment of proliferating cell nuclear antigen expression. Placenta, 15:551-556

Johnston SD, Raksil S. 1987. Fetal loss in the dog and cat. Vet Clin North Am Small Anim Pract, 17:535-554.

Kehrer A. 1973. Chorionic development and structure of the placenta zonaria in the cat, dog and fox [in Germany]. Z Anat Entwicklungsgesch, 143:25-42.

King GJ, Atkinson BA, Robertson HA. 1980 Development of the bovine placentome from days 20 to 29 of gestation. J Reprod Fertil, 59:95-100.

Klein C, Scoggin KE, Ealy AD, Troedsson MH. 2010. Transcriptional profiling of equine endometrium during the time of maternal recognition of pregnancy. Biol Reprod, 83:102-113.

Klein C, Troedsson MH. 2011a. Maternal recognition of pregnancy in the horse: a mystery still to be solved. Reprod Fertil Dev, 23:952-963.

Klein C, Troedsson MH. 2011b. Transcriptional profiling of equine conceptuses reveals new aspects of embryo-maternal communication in the horse. Biol Reprod, 84:872-885.

Klisch K, Hecht W, Pfarrer C, Schuler G, Hoffman B, Leiser R. 1999. DNA content and ploidy level of bovine placentomal trophoblast giant cells. Placenta, 59:425-430

Klisch K, Bevilacqua E, Olivera LV. 2005. Mitotic polyploidization in trophoblast giant cells of the alpaca. Cells Tissues Organs, 181:103-108.

Klonisch T, Mathias S, Cambridge G, HombachKlonisch S, Ryan PL, Allen WR. 1997. Placental localization of relaxin in the pregnant mare. Placenta, 18:121-128.

Klonisch T, Hombach-Klonisch S, Froehlich

C, Kauffold J, Steger K, Huppertz B. 1999. Fischer

B. Nucleic acid sequence of feline preprorelaxin and its localization within the feline placenta. Biol Reprod, 60:305-311.

Klonisch T, Kauffold J, Steger K, Bergmann M, Leiser R, Fischer B, Hombach- Klonisch S. 2001. Canine relaxin-like factor: unique molecular structure and differential expression within reproductive tissues of the dog. Biol Reprod, 64:442-450.

Kovacs WJ. Ojeda SR. 2012. Fertilization, implantation, and endocrinology of pregnancy. In: Kovacs WJ, Ojeda SR (Ed.). Textbook of Endocrine Physiology. New York, NY: Oxford University Press. pp. 264-291.

Kowalewski MP, Michel E, Gram A, Boos A, Guscetti F, Hoffmann B. Aslan S, Reichler I. 2011. Luteal and placental function in the bitch: spatiotemporal changes inprolactin receptor (PRLr) expression at dioestrus, pregnancy and normal and induced parturition. Reprod Biol Endocrinol, 9:109. doi:10.1186/1477-7827-9-109.

Kridli RT, Khalaj K, Bidarimath M, Tayade C. 2016. Placentation, maternal-fetal interface, and conceptus loss in swine. Theriogenology, 85:135-144.

Kuribayashi T, Shimada T, Matsumoto M, Kawato K, Honjyo T, Fukuyama M, Yamamoto Y, Yamamoto S. 2003. Determination of serum Creactive protein (CRP) in healthy beagle dogs of various ages and pregnant beagle dogs. Exp Anim, 52:387-390.

Kydd JH, Butcher GW, Antczak DF, Allen WR. 1991. Expression of major histocompatibility complex (MHC) class 1 molecules on early trophoblast. J Reprod Fertil, 44:463-477.

Kuribayashi T, Shimada T, Matsumoto M, Kawato K, Honjyo T, Fukuyama M, Leiser R, Koob B. 1993. Development and characteristics of placentation in a carnivore, the domestic cat. J Exp Zool, 266:642-656.

Leiser R, Kaufmann P. 1994. Placental structure: in a comparative aspect. Exp Clin Endocrinol, 102:122-134.

Maher JK, Tresnan DB, Deacon S, Hannah L, Antczak DF. 1996. Analysis of MHC class I expression in equine trophoblast cells using in situ hybridization. Placenta, 17:351-359.

Majewska M, Panasiewicz G, Klisch $\quad K$, Olivera LV, Mamani JM, Abd-EInaeim MM. Szafranska B. 2009. Pregnancy-associated glycoprotein (PAG) family: transcripts and gene amplicons in camelids. Reprod Biol, 9:127-150.

McNaughton AP, Murray RD. 2009. Structure and function of the bovine fetomaternal unit in relation to the causes of retained fetal membranes. Vet Rec, 165:615-622.

Meinecke B, Kuiper $\quad$ H, Drögemüller $\quad$ C, Leeb T, Meinecke-Tillmann S. 2003. A mola hydatidosa coexistent with a foetus in a bovine freemartin pregnancy. Placenta, 24:107-112.

Miglino MA, Ambrósio CE, dos Santos Martins D, Wenceslau CV, Pfarrer C, Leiser R. 2006. The carnivore pregnancy: the development of the embryo 
and fetal membranes. Theriogenology, 66:1699-1702. Mordak R, Stewart PA. 2015. Periparturient stress and immune suppression as a potential cause of retained placenta in highly productive dairy cows: examples of prevention. Acta Vet Scand, 57:84. doi:10.1186/s13028015-0175-2

Morris FJ, Kerr SM, Laven RA, Collett MG. 2008 Large hydatidiform mole: an unusual finding in a calving cow. $N \quad Z$ Vet J,56:243-246. doi: 10.1080/00480169.2008.36841.

Nakano H, Shimada A, Imai $\quad K$, Takezawa T, Takahashi T, Hashizume K. 2002. Bovine trophoblastic cell differentiation on collagen substrata: formation of binucleate cells expressing placental lactogen. Cell Tissue Res, 307:225-235.

Noronha LE, Antczak DF. 2010. Maternal immune responses to trophoblast: the contribution of the horse to pregnancy immunology. Am J Reprod Immunol, 64:231244.

Olio RL, Lobo LM, Pereira MA, Santos AC, Viana DC, Favaron PO, Miglino MA. 2014. Accessory placental structures: a review. Open J Anim Sci, 4:305312. http://dx.doi.org/10.4236/ojas.2014.45039.

Orfanou DC, Ververidis HN, Pourlis A, Fragkou IA, Kokoli AN, Boscos CM, Taitzoglou IA, Tzora A, Nerou CM, Athanasiou L, Fthenakis GC. 2009. Postpartum involution of the canine uterus - gross anatomical and histological features. Reprod Domest Anim, 44:152-155.

Oriol JG, Sharom FJ, Betteridge KJ. 1993 Developmentally regulated changes in the glycoproteins of the equine embryonic capsule. $J$ Reprod Fertil, 99:653-664

Peippo J, Machaty Z, Peter A. 2011. Terminologies for the pre-attachment bovine embryo. Theriogenology, 76:1373-1379.

Peter AT. 2013. Bovine placenta: a review on morphology, components, and defects from terminology and clinical perspectives. Theriogenology, 80:693-705.

Peter AT. 2015. Retained fetal membranes. In: Hopper RM (Ed.). Bovine Reproduction. Hoboken, NJ: Wiley Blackwell. pp. 431-439.

Raheem KA. 2017. An insight into maternal recognition of pregnancy in mammalian species. J Saudi Soc Agric Sci, 16:1-6. doi:10.1016/j.jssas.2015.01.002.

Ranilla MJ, Sulon J, Carro MD, Mantecón AR, Beckers JF. 1994. Plasmatic profiles of pregnancy-associated glycoprotein and progesterone levels during gestation in Churra and Merino sheep. Theriogenology, 42:537-545.

Rapacz-Leonard A, Dąbrowska M, Janowski $\quad T$. 2014. Major histocompatibility complex I mediates immunological tolerance of the trophoblast during pregnancy and may mediate rejection during parturition. Mediators Inflamm, 2014: 579279 doi:10.1155/2014/579279.

Reberg S, Peter AT, Blevins W. 1992. Subinvolution of placental sites in dogs. Compend Contin Educ Pract Vet, 4:789-796.

Reimers TJ, Ullmann $\quad$ MB, Hansel $\quad$ W. 1985. Progesterone and prostanoid production by bovine binucleate trophoblastic cells. Biol Reprod, 33:1227-
1236.

Reynaud K, Fontbonne A, Marseloo N, Viaris de Lesegno C, Saint-Dizier M, Chastant-Maillard S. 2006. In vivo canine oocyte maturation, fertilization and early embryogenesis. A review. Theriogenology, 66:1685-1693.

Roberts RM. 1989. Conceptus interferons and maternal recognition of pregnancy. Biol Reprod, 40:449-452.

Roberts RM, Cross JC, Leaman DW. 1992. Interferons as hormones of pregnancy. Endocr Rev, 13:432-452.

Roberts SJ. 1971. Veterinary Obstetrics and Genital Diseases (Theriogenology). Woodstock, VT: Published by the author.

Robertson R, Allen H, Bokelman D. 1979. Aspirin: teratogenic evaluation in the dog. Teratology, 20:313320.

Ross JW, Malayer JR, Ritchey JW, Geisert RD. 2003. Characterization of the interleukin-1beta system during porcine trophoblastic elongation and early placental attachment. Biol Reprod, 69:1251-1259.

Sahlfeld L, Hazzard T, Kutzler M. 2012. Cellular characteristics of cultured canine trophoblasts. Reprod Domest Anim, 47:161-164.

Samuel CA, Allen WR, Steven DH. 1974. Studies on the equine placenta. I. Development of the microcotyledons. J Reprod Fertil, 4:441-445.

Schuler G, Ozalp GR, Hoffmann B, Harada N, Browne P, Conley AJ. 2006. Reciprocal expression of 17alpha-hydroxylase-C17,20-lyase and aromatase cytochrome P450 during bovine trophoblast differentiation: a two-cell system drives placental oestrogen synthesis. Reproduction, 131:669-679.

Schuler G, Greven H, Kowalewski MP, Döring B, Ozalp GR, Hoffmann B. 2008. Placental steroids in cattle: hormones, placental growth factors or byproducts of trophoblast giant cell differentiation? Exp Clin Endocrinol Diabetes, 116:429-436.

Skidmore JA, Wooding FB, Allen WR. 1996. Implantation and early placentation in the onehumped camel (Camelus dromedarius). Placenta, 17:253-262.

Smith T. 1919. A characteristic localization of Bacillus abortus in the bovine fetal membranes. $J$ Exp Med, 29:451-456.

Soares MJ. 2004. The prolactin and growth hormone families: pregnancy-specific hormones/cytokines at the maternal-fetal interface. Reprod Biol Endocrinol, 2:51. doi: 10.1186/1477-7827-2-51.

Sontas HB, Stelletta C, Milani C, Mollo A, Romagnoli S. 2015. Full recovery of subinvolution of placental sites in an American Staffordshire terrier bitch. J Small Anim Pract, 52:42-45.

Sousa NM, Garbayo JM, Figueiredo JR, Sulon J, Gonçalves PBD, Beckers JF. 1999. Pregnancyassociated glycoprotein and progesterone profiles during pregnancy and postpartum in native goats from the north-east of Brazil. Small Rumin Res, 32:137-147.

Sousa NM, Ayad A, Beckers JF, Gajewski Z. 2006. Pregnancy-associated glycoproteins (PAG) as pregnancy markers in the ruminants. $J$ Physiol 
Pharmacol, 57:153-171.

Sousa NM, Beckers JF, Gajewski Z. 2008. Current trends in follow-up of trophoblastic function in ruminant species. J Physiol Pharmacol, 59:65-74.

Staun-Ram E, Shalev E. 2005. Human trophoblast function during the implantation process. Reprod Biol Endocrin, 3:56. doi:10.1186/1477-7827-3-56.

Steven DH. 1982. Placentation in the mare. J Reprod Fertil, 31:41-55.

Stout TA, Meadows S, Allen WR. 2005. Stagespecific formation of the equine blastocyst capsule is instrumental to hatching and to embryonic survival in vivo. Anim Reprod Sci, 87:269-281.

Szafrañska B, Panasiewicz G. 2002. The placental expression of the porcine pregnancy-associated glycoprotein (pPAG) gene family examined in situ and in vitro. Anim Reprod Sci, 72:95-113.

Tibary A. 2001. Fertilization, embryo and fetal development in camelids. In: Proceedings of the Annual Conference of the Society for Theriogenology, 2001, Vancouver, BC, Canada. Montgomery, AL: Society for Theriogenology. pp. 387-396.

Tsutsui T, Amano T, Shimizu T, Murao I, Stabenfeldt GH. 1989. Evidence for transuterine migration of embryos in the domestic cat. Nihon Juigaku Zasshi, 51:613-617.

Tsutsui T, Stewart DR. 1991. Determination of the source of relaxin immunoreactivity during pregnancy in the dog. J Vet Med Sci, 53:1025-1029.

Tsutsui T, Stabenfeldt GH. 1993. Biology of ovarian cycles, pregnancy and pseudopregnancy in the domestic cat. J Reprod Fertil, 47:29-35.

Ulutas PA, Musal B, Kiral F, Bildik A. 2009. Acute phase protein levels in pregnancy and oestrus cycle in bitches. Res Vet Sci, 86:373-376.

Van Mourik M., Macklon N. Heijnen C. 2009 Embryonic implantation: cytokines, adhesion molecules, and immune cells in establishing an implantation environment. J Leukocyte Biol, 85:4-19.

Waelchli RO, Bettreridge KJ. 2013. Morphology of twin and triplet equine conceptuses during weeks 3 and 4 of pregnancy. Reprod Fertil Dev, 25:762-774.

Weber JA, Freeman DA, Vanderwall DK, Woods GL. 1991. Prostaglandin E2 hastens oviductal transport of equine embryos. Biol Reprod, 45:544-546.
Whitlock BK, Maxwell HS. 2008. Pregnancyassociated glycoproteins and pregnancy wastage in cattle. Theriogenology, 70:550-559.

Wilsher S, Allen WR. 2011. Intrauterine administration of plant oils inhibits luteolysis in the mare. Equine Vet $J, 43: 99-105$.

Wooding FB, Wathes DC. 1980. Binucleate cell migration in the bovine placentome. $J$ Reprod Fertil, 59:425-430.

Wooding FB, Staples LD, Peacock MA. 1982. Structure of trophoblast papillae on the sheep conceptus at implantation. J Anat, 134:507-516.

Wooding FB, Beckers JF. 1987. Trinucleate cells and the ultrastructural localisation of bovine placental lactogen. Cell Tissue Res, 247:667-673.

Wooding FB. 1992. Current topic: the synepitheliochorial placenta of ruminants: binucleate cell fusions and hormone production. Placenta, 13:101113.

Wooding FB, Hobbs T, Morgan G, Heap RB, Flint APF. 1993. Cellular dynamics of growth in sheep and goat synepitheliochorial placentomes: an autoradiographic study. J Reprod Fertil, 98:275-283.

Wooding FB, Ozturk M, Skidmore JA, Allen WR. 2003. Developmental changes in localization of steroid synthesis enzymes in camelid placenta. Reproduction, 26:239-247.

Wooding FB, Roberts RM, Green JA. 2005. Light and electron microscope immunocytochemical studies of the distribution of pregnancy associated glycoproteins (PAGs) throughout pregnancy in the cow: possible functional implications. Placenta, 26:807-827.

Wooding P, Burton G. 2008. Comparative placentation: Structures, Functions and Evolution. Heidelberg: Springer. 301 pp.

Yamashita K, Fujinaga T, Miyamoto T, Hagio M, Izumisawa Y, Kotani T. 1994. Canine acute phase response: relationship between serum cytokine activity and acute phase protein in dogs. J Vet Med Sci, 56:487492.

Zoli AP, Demez P, Beckers JF, Reznik M, Beckers A. 1992. Light and electron microscopic immunolocalization of bovine pregnancyassociated glycoprotein in the bovine placentome. Biol Reprod, 46:623-629. 